\title{
Pengembangan Permukiman Pesisir Sukolilo Menggunakan Konsep Arsitektur Kontekstual (Studi Kasus: Kampung Nelayan Sukolilo Baru, Surabaya)
}

\author{
Franciscus Immanuel Mintardjo ${ }^{1 *}$, Rizal Jannatan Firdaus ${ }^{1}$, Sri Suryani Yuprapti Winasih ${ }^{1}$
}

\author{
${ }^{1}$ Department of Architecture, Faculty of Architecture and Design, UPN "Veteran” Jawa Timur \\ *Penulis Korespondensi: srisuryani.ar@upnjatim.ac.id
}

\begin{abstract}
Abstrak:
Kebutuhan akan lahan hunian merupakan masalah yang sering dijumpai pada masa kini. Salah satu faktor utamanya adalah semakin terbatasnya keberadaan lahan, terutama di kawasan pesisir yang penyelesaiannya sering di wujudkan dengan menambah luas lahan permukiman melalui reklamasi pada batas-batas pantai. Seperti halnya pada kampung nelayan Sukolilo, dikarenakan keterbatasan lahan di permukiman, berdampak pada kurangnya fasilitas penunjang seperti ruang terbuka. Konversi lahan juga banyak dijumpai di jalan lingkungan kampung, jalan dan teras rumah di alih fungsi menjadi tempat penunjang ekonomi. Solusi yang dilakukan oleh masyarakat yaitu reklamasi dalam skala kecil dan bertahap pada bibir pantai pesisir tersebut. Namun, reklamasi belum tergolong solutif bagi permukiman pesisir ini. Reklamasi secara massif dan spontan menimbulkan trauma pada ekosistem lingkungan eksisting. Tujuan karya ilmiah ini adalah memberikan solusi dengan menerapkan metode perancangan kontekstual pada kawasan pesisir dengan harapan agar terciptanya lingkungan dan cara hidup yang baru bagi masyarakat pesisir Sukolilo. Penelitian ini merupakan penelitian deskriptif - kualitatif dengan pendekatan partisipatif. Penyelesaian Rancangan dilakukan dengan metode pendekatan arsitektur kontekstual. Data yang dibutuhkan dalam merancang dilakukan dengan metode mengumpulkan data kualitatif melalui observasi, pengumpulan data visual, dan wawancara dengan warga setempat dari kampung nelayan Sukolilo, serta pengumpulan data dari dokumen literatur dan teori yang telah ada. Hasil dari perancangan adalah pengembangan kawasan pesisir dalam bentuk permukiman terapung yang memertahankan konteks lokal sebagai alternatif dari upaya reklamasi wilayah pesisir.
\end{abstract}

Kata Kunci: permukiman; pesisir; pengembangan; kontekstual

\section{Pendahuluan}

Manusia sebagai bagian dari ekosistem secara berkelompok membentuk lingkungan permukiman sebagai tempat tinggalnya. Disebutkan dalam pasal 1 ayat 5, Undang Undang RI Nomor 11 tahun 2011 tentang Perumahan dan Kawasan Permukiman, "Permukiman adalah bagian dari lingkungan hunian yang terdiri atas lebih dari satu satuan perumahan yang mempunyai prasarana, sarana, utilitas umum, serta mempunyai penunjang kegiatan fungsi lain di kawasan perkotaan atau kawasan perdesaan". Permukiman secara fisik tidak terbatas pada tempat tinggal, tetapi merupakan satu kesatuan sarana dan prasarana lingkungan terstruktur. Hubungan yang terbentuk, tercermin dari kegiatan manusia pada lingkungan permukimannya melalui pola-pola mengatur dan menjaga keseimbangan alam. Beberapa aspek yang perlu diperhatikan dalam perancangan lingkungan, seperti akar budaya lokal dapat diangkat menjadi sesuatu yang menguntungkan secara ekonomi sosial, budaya. Lingkungan permukiman yang baik berpotensi meningkatkan citra dari suatu kawasan. Hal ini dapat dijadikan obyek utama untuk meningkatkan citra khusus dari suatu wilayah. Perencanaan permukiman yang mempertimbangkan potensi masyarakat setempat merupakan hal penting untuk menumbuhkan rasa memiliki dan akan mendorong untuk merawat daerahnya.

Kampung Nelayan Sukolilo adalah salah satu permukiman penduduk yang berada di wilayah pesisir Timur Surabaya. Disebut kampung nelayan karena sebagian besar penduduknya bermata pencaharian sebagai nelayan atau bergantung pada hasil laut. Kampung nelayan Sukolilo termasuk dalam wilayah kecamatan Bulak, Kelurahan Kenjeran Surabaya. Lokasi kampung berdekatan dengan area wisata yaitu Wisata Pantai Kenjeran dan Taman Ria Kenjeran. Struktur sosial kehidupan masyarakat kampung Nelayan Sukolilo Baru tersebut menjunjung tinggi kerukunan dan hidup bergotong royong. Dalam bermasyarakat warga Kampung Nelayan Sukolilo Baru mengutamakan musyawarah-mufakat untuk mengambil keputusan bila terjadi permasalahan khususnya dalam proses mendirikan bangunan baru dilingkungan kampung tersebut. Keterbatasan lahan permukiman seringkali menimbulkan permasalahan dalam menata permukiman pada kawasan Kampung Nelayan Sukolilo. Untuk memenuhi kebutuhan lahan masyarakat bersepakat dengan mereklamasi pantai secara bertahap. Setiap tahap reklamasi yang dilakukan menghasilkan luas tanah berukuran $5 \times 5$ meter, dengan biaya lebih kurang 50 juta rupiah", kata Anang Purwanto, ketua RW Kampung Nelayan Sukolilo. 

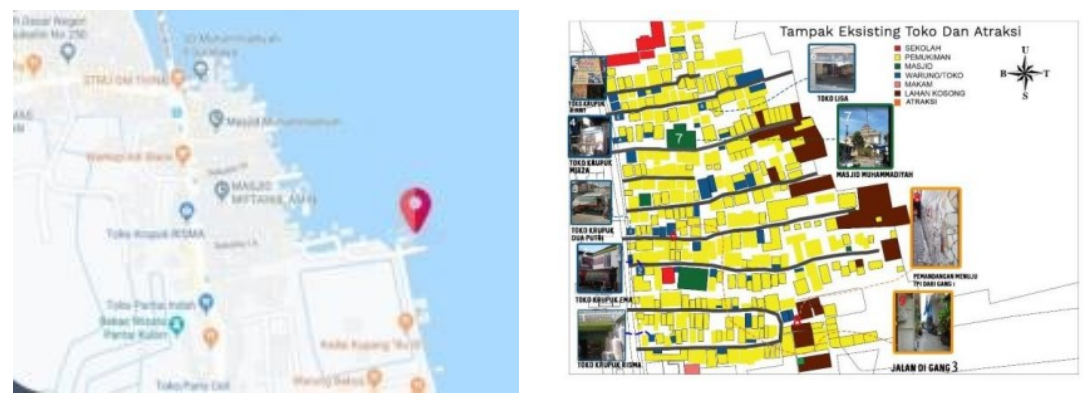

Gambar 1. Peta lokasi Kampung Nelayan Sukolilo

(Sumber: Google Maps).

Proses reklamasi awalnya sebagai upaya untuk memenuhi kebutuhan ruang produksi yaitu sebagai tempat olahan hasil laut yaitu tempat menjemur sisa hasil laut yang tidak terjual dan poduk olahan lain seperti kerupuk. Lahan hasil reklamasi tersebut didirikan instalasi dari bambu setinggi kurang lebih $175-180 \mathrm{~cm}$ diatas tiang-tiang bamboo ini digunakan sebagai tempat menjemur ikan.

Reklamasi pantai yang dilakukan masyarakat nelayan sukolilo baru ini bukan solusi yang tepat untuk menambah luas lahan permukiman karena banyak mengakibatkan kerugian, salah satunya kerusakan ekosistem laut yang akan berdampak pada rusaknya sumber mata pencahariannya. Selain itu, dengan melakukan reklamasi, usaha pengendalian terhadap bangunan yang terbangun di masa mendatang akan memerlukan usaha lebih.

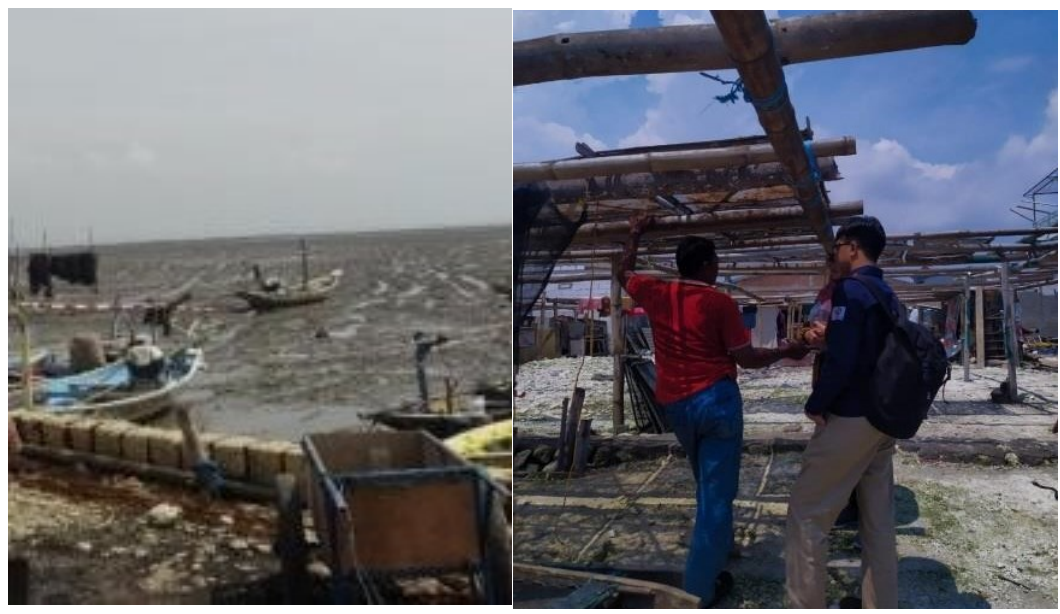

Gambar 2. Bentuk reklamasi warga setempat

(Sumber: dokumen penulis).

\subsection{Permukiman Pesisir}

Pengertian kawasan pesisir seperti yang ditulis dalam naskah akademik pengelolaan wilayah pesisir (2001) adalah "wilayah pesisir tertentu yang ditunjuk atau ditetapkan oleh pemerintah berdasarkan kriteria tertentu, seperti karakteristik fisik, biologi, sosial, dan ekonomi untuk dipertahankan keberadaannya". Menurut Suprihayono (2007: 14) wilayah pesisir adalah wilayah pertemuan antara daratan dan laut ke arah darat wilayah pesisir meliputi bagian daratan, baik kering maupun terendam air, yang masih dipengaruhi oleh sifat-sifat laut seperti pasang surut, angin laut, dan perembesan air asin. Sedangkan ke arah laut wilayah pesisir mencakup bagian laut yang masih dipengaruhi oleh proses alami yang terjadi di darat seperti sedimentasi dan aliran air tawar, maupun yang disebabkan karena kegiatan manusia di darat seperti penggundulan hutan dan pencemaran. Menurut UU No. 27 Tahun 2007 Tentang, batasan wilayah pesisir adalah kearah daratan mencakup wilayah administrasi daratan dan kearah perairan laut sejauh 12 (dua belas) mil laut diukur dari garis pantai ke arah laut lepas dan/atau kearah perairan kepulauan.

Pola perkembangan daerah terbangun (built up areas) di daerah pantai menurut Sujarto dalam Mulyadi, 2005: 101, adalah: Daerah Desa Pantai, perkembangan dan pertumbuhan dimulai oleh terbentuknya kelompok masyarakat yang mata pencahariannya nelayan. Pemukiman umumnya berorientasi ke arah laut karena usaha utama dari hasil laut. Biasanya daerah terbangun terpencar-pencar di tepi pantai sesuai dengan potensi kebutuhan masyarakat. 


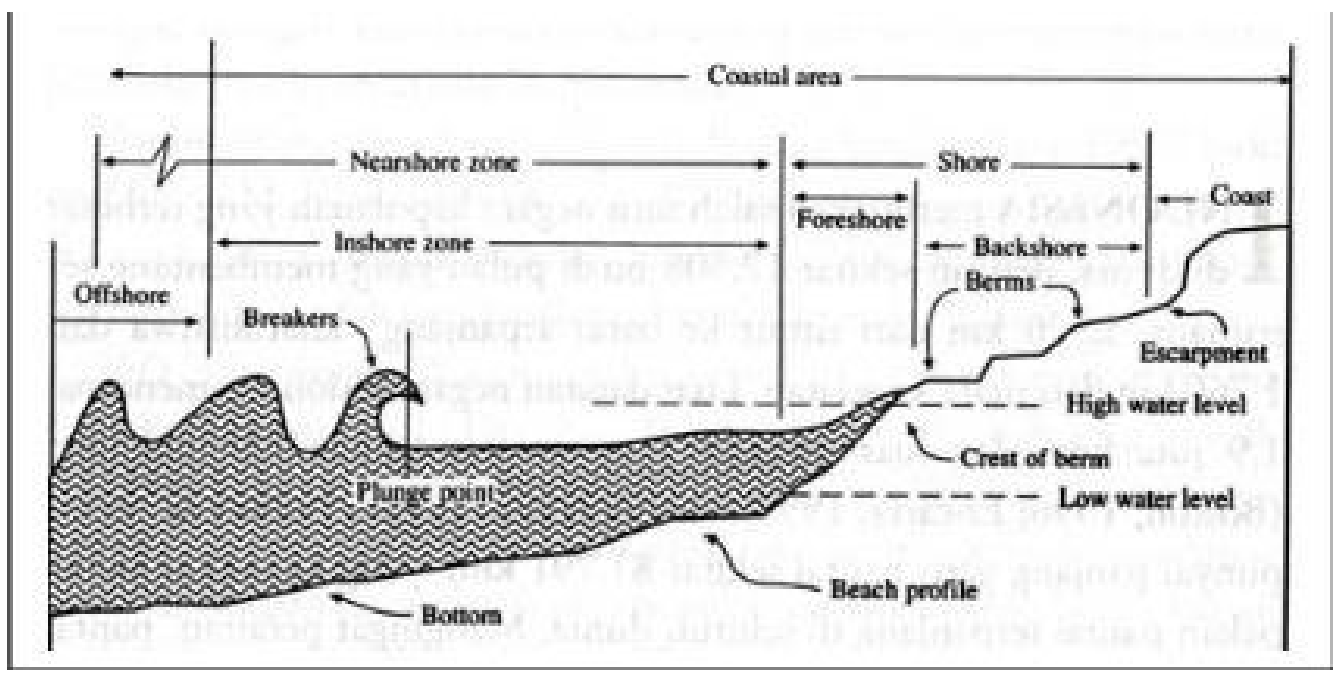

Gambar 3. Batas fisik wilayah pesisir

(Sumber: Bhratz dalam Supriharyono, 2002:2).

Maka dari itu, solusi yang ditawarkan penulis dengan permasalahan ini adalah mengembangkan pola pemanfaatan dan penataan ruang pada permukiman terapung. Dengan metode tersebut, diharapkan dapat menekan biaya dalam pengembangan suatu kawasan dan meningkatkan efektifitas serta efisiensi dalam sistem pengendalian pengembangan kawasan pesisir tersebut.

Permukiman terapung berbeda dengan reklamasi. Meskipun sama-sama menambah luasan wilayah di atas laut, tetapi permukiman terapung tetap berusaha menonjolkan aspek kontekstual yang lebih ramah terhadap kawasan tersebut. Dengan metode ini, diharapkan tercipta kesinambungan antara bangunan lama dengan bangunan baru yang dimana hal ini tidak berseberangan dengan nilai-nilai yang sudah terbangun dari eksisting kawasan tersebut.

Langkah mengembangkan permukiman di tepi pantai karena keterbatasan lahan, dapat dengan membuat permukiman baru di atas laut sehingga meminimalisir resiko kerusakan bawah laut. Dikarenakan permukiman ini tidak perlu mengubah batas pantai dengan cara mengurug, melainkan dengan membangun pondasi di laut dan bangunan di atasnya. Dengan hal ini, konteks fisik pantai dan laut tidak akan berubah terlalu secara ekstrim dari eksistingnya.

\subsection{Pendekatan Arsitektur Kontekstual}

Dalam pemikiran kontekstual, kehadiran bentuk bangunan tidak terjadi secara begitu saja, tetapi berdasarkan bentuk yang telah diakui oleh masyarakat sekelilingnya. Prinsip ini mencakup pengertian bahwa kehadiran suatu bentuk merupakan pengembangan dari suatu kondisi yang telah ada sebelumnya. Secara garis besar pengertian dari arsitektur kontekstual adalah sebuah metode pendekatan perancangan arsitektur, dimana rancangan akan diwujudkan dengan adanya kesinambungan dengan lingkungan sekitarnya. Dalam Arsitektur, konteks melibatkan hubungan khusus suatu bangunan dengan lingkungannya, sebagaimana hubungan antara bangunan dengan tapaknya (site), yang dapat terlihat dari bentuk fisiknya dan bentuk morfologinya. Dalam arti yang lebih luas, konteks dapat juga berarti bagian dari suatu lokasi, baik lokasi yang terletak di daerah pinggiran kota, di daerah perkotaan atau di daerah pedesaan. Dalam hal ini, konteks yang dimaksud adalah daerah pesisir.

Menurut Roger Trancik, Finding Lost Space (1986), Three Theories of Urban Spatial Design; yaitu massa dan ruang (figure), jejalur atau keterhubungan (linkage), dan tempat (place). Kualitas sebuah ruang publik dipengaruhi oleh bentuk dan tatanan ruang, dan juga terhubung dengan mudah jika dirancang dengan benar akan menghasilkan ruang berkegiatan yang tak hanya nyaman, tetapi juga membentuk perilaku positif bagi manusia di dalamnya. Selain itu, konteks budaya, sejarah, dan ekologi juga perlu diperhatikan dengan menyatukan bentuk, detail, ornamen yang unik sesuai nilai sosial, budaya dan persepsi visual; sehingga menghasilkan ruang publik yang memiliki karakteristik lokal.

Kontekstualisme dalam arsitektur diterapkan dalam perancangan sebuah bangunan atau ruang di dalam kota, sehingga kota tersebut akan memiliki ciri khas (karakteristik) tersendiri yang pada akhirnya akan menghasilkan sebuah city branding yang unik dan tidak dimiliki kota lain. Alhamdani (2010), mencatat elemen kontekstual tergantung pada banyak faktor, di antaranya: Fitur fisik bangunan; konfigurasi letak bangunan (bentuknya secara fisik atau faktor-faktor yang menunjangnya), konteks terhadap tapak (site) bangunan (faktor yang menampilkan 
nilai-nilai memori masa lalu), konteks terhadap bangunan-bangunan temporal (bangunan-bangunan yang sudah terbangun atau yang akan dibangun), Batasan/perletakan bangunan (ada dipinggiran kota atau pusat kota), bagaimana bangunan berkaitan dengan daerah sekitarnya dan dengan bangunan yang berdekatan; kontras dalam gaya bangunan atau material dalam artian memiliki kesamaan atau saling mempengaruhi. Dan kecocokan bangunan dalam kaitan hubungannya dengan bangunan sekitarnya. Merancang bangunan dengan menyediakan visualisasi yang cukup antara bangunan yang sudah ada dengan bangunan baru untuk menciptakan suatu efek yang kohesif (menyatu).

Peter Calthorpe dan William Fulton dalam buku The Regional City menjabarkan asas yang disebut sebagai Principle of Diversity, Conservation, and Human Scale; "Prinsip alternatif ini berlaku sama untuk dimensi sosial, ekonomi, dan fisik masyarakat. Misalnya, implikasi sosial dari skala manusia dapat berarti lebih banyak petugas polisi yang berjalan daripada melayang di atas helikopter; implikasi ekonomi skala manusia dapat berarti kebijakan ekonomi yang mendukung bisnis lokal kecil daripada industri dan perusahaan besar, dan implikasi fisik skala manusia dapat diwujudkan dalam bentuk dan detail bangunan yang berkaitan dengan jalan." Dalam perancangan kawasan pesisir, penulis menerapkan sistem pengembangan kawasan secara mengelompok (clustered). Dalam hal ini pengembangan daerah pesisir diarahkan ke pedalaman. Dengan konsepsi ini diharapkan permasalahan yang mungkin dapat ditimbulkan oleh penggunaan lahan pantai secara ekstensif sepanjang pesisir dapat dibatasi. Demikian juga akibat yang mungkin dapat ditimbulkan sehubungan dengan gangguan terhadap kelestarian lingkungan hidup dapat dibatasi dan dialokasikan kearah tertentu yang memungkinkan pengontrolan yang lebih efektif (Mulyadi dalam Baun, 2008:45). Selain itu, penulis menerapkan pola pengendalian sectoral yaitu suatu pola penguasaan atau pengendalian yang berbentuk sektoral yang memusat di suatu daerah hulu sungai dan melebar sepanjang daerah aliran sungai sampai ke daerah pantai. Pola pengendalian dan penguasaan ini sangat penting dalam rangka penataan pengembangan suatu daerah aliran sungai yang potensial. (Baun, 2008:47)

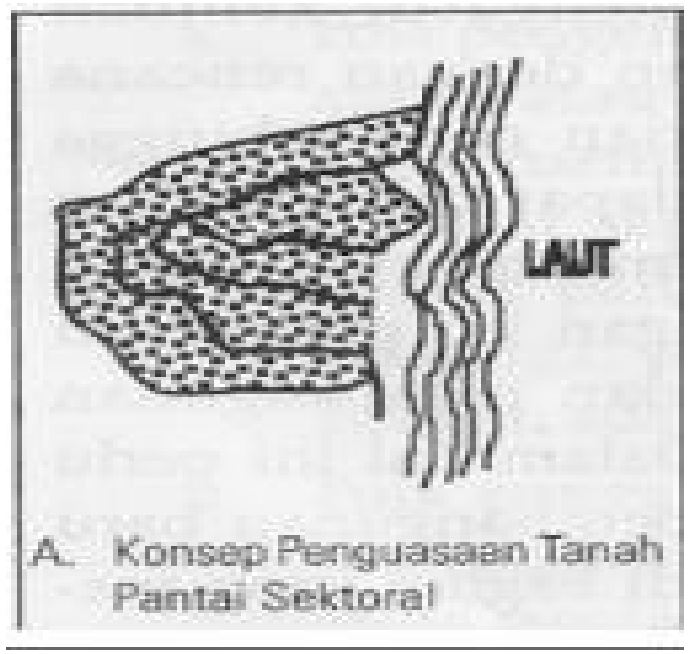

Gambar 4. Pola Pengendalian Sektoral

(Sumber: Sujarto dalam Mulyadi, 2005:110).

Perancangan dengan konsep ini diharapkan hasil rancangan permukiman dapat menyelesaikan permasalahan terkait keterbatasan lahan bermukim yang terjadi pada Kawasan Kampung Nelayang Sukolilo Baru.

\section{Metode}

Pendekatan yang digunakan dalam perancangan Kampung nelayan Sukolilo menggunakan pendekatan partisipatif. Penelitian Partisipatoris adalah metode riset yang bersifat dari atas ke bawah (bottom-up) dimana peneliti berusaha untuk memberikan dorongan serta mendukung masyarakat dalam melakukan berbagai kegiatan keseharlan. Diantaranya seperti;1) Melakukan identifikasi kebutuhan mereka sendiri. 2) Menetapkan tujuan mereka sendiri dan 3) Memonitor dan mengevaluasi kinerja mereka sendiri (Kemmis \& Taggart, 2007).

Penelitian partisipatori adalah metode riset yang memberikan komitmen dalam model pembangunan dengan menyoroti dari aspek sosial, ekonomi, dan politik yang semua itu dilakukan untuk upaya memenuhi kebutuhan hidup masyarakat. Ciri Penelitian Partisipatoris, 1) Sebelum melakukan penelitian, peneliti harus merencanakan program dengan ikut melaksanakan program, serta mengkaji program dan pelaksanaan program secara terus menerus. 2) Peneliti dan obyek teliti bekerja secara bersama-sama untuk dapat mengevaluasi dampak dari program yang dipergunakan sebagai upaya memperoleh stimulasi yang pas untuk organisasi, institusi, lembaga dalam kehidupan masyarakat. 3) Peneliti secara aktif terlibat secara terus menerus mulai dari awal penelitian hingga akhir, 
sehingga prosesi keterlibatan ini juga menjadi bagian daripada tahapan penelitian.

Pendekatan partisipatif pada hakekatnya adalah implementasi dari pemberdayaan masyarakat karena pendekatan ini mengakui bahwa hak bagi penduduk lokal untuk mengawasi dan terlibat dalam proses pembuatan keputusan dan melaksanakan keputusan itu. Dalam pendekatan partisipatif mampu untuk mengidentifikasi pertanyaanpertanyaan yang relevan. Penelitian partisipatoris menjamin bahwa pusat perhatian evaluasi pada pertanyaanpertanyaan yang diungkapkan kepada responden memiliki sifat lokal yang relevan dalam memenuhi kebutuhan perencana. Melakukan penelitian partisipatoris berarti meningkatkan pembelajaran bagi para peserta dan merupakan kesempatan untuk memperkenalkan dan memperkuat ketrampilan merencanakan, melaksanakan, dan mengevaluasi program. dimana keterlibatan masyarakat dalam perancangan sangat dibutuhkan. Masukan yang diberikan masyarakat sebagai penghuni yang tinggal di permukiman tersebut menjadi pertimbangan penting. Diharapkan hasil yang diperoleh dapat dimanfaatkan oleh masyarakat penghuni secara maksimal. Sedangkan konsep perancangan yang digunakan adalah arsitektur kontekstual. Kontekstual, dalam perancangan merupakan suatu perencanaan yang memperhatikan hubungan antara bangunan dengan lingkungan yang ada di sekitarnya. melakukan studi terhadap kesulitan-kesulitan yang timbul dalam menciptakan keserasian antar bangunan yang berbeda jaman dan gaya, dalam suatu lokasi yang berdekatan (Brolin, 1980).

Tahap yang dilakukan dalam merencanakan kawasan Kampung Nelayan Sukolilo Baru adalah 1) Mendefinisikan Kawasan Kampung Nelayan Sukolilo Baru untuk mendapatkan pengertian objek yang dibangun. 2). Mengidentifikasi konteks dan aspek lokal Kawasan Kampung Nelayan Sukolilo yang menjadi poin-poin pengembangan rancangan Kawasan Kampung Nelayan Sukolilo dengan metode pengumpulan data kualitatif dengan langkah observasi, pengumpulan data visual, dan wawancara dengan warga asli dari kampung nelayan Sukolilo. 3) Mengumpulkan literatur terkait pengembangan Kawasan Kampung Nelayan yaitu Konsep Arsitektur Kontekstual dan Desa Terapung (floating village) untuk mendapatkan gambaran dan pemahaman terkait kegiatan pengembangan fasilitas kampung. 4) Merancang kawasan berdasarkan kebutuhan warga Kampung Nelayan Sukolilo didukung gambaran kegiatan serta fasilitas dari literatur.

\section{Hasil dan Pembahasan}

Hasil analisa data yang dikumpulkan, selanjutnya disusun konsep rancangan yang dibagi menjadi 2 konsep besar yaitu:

\subsection{Konsep Cluster Zoning}

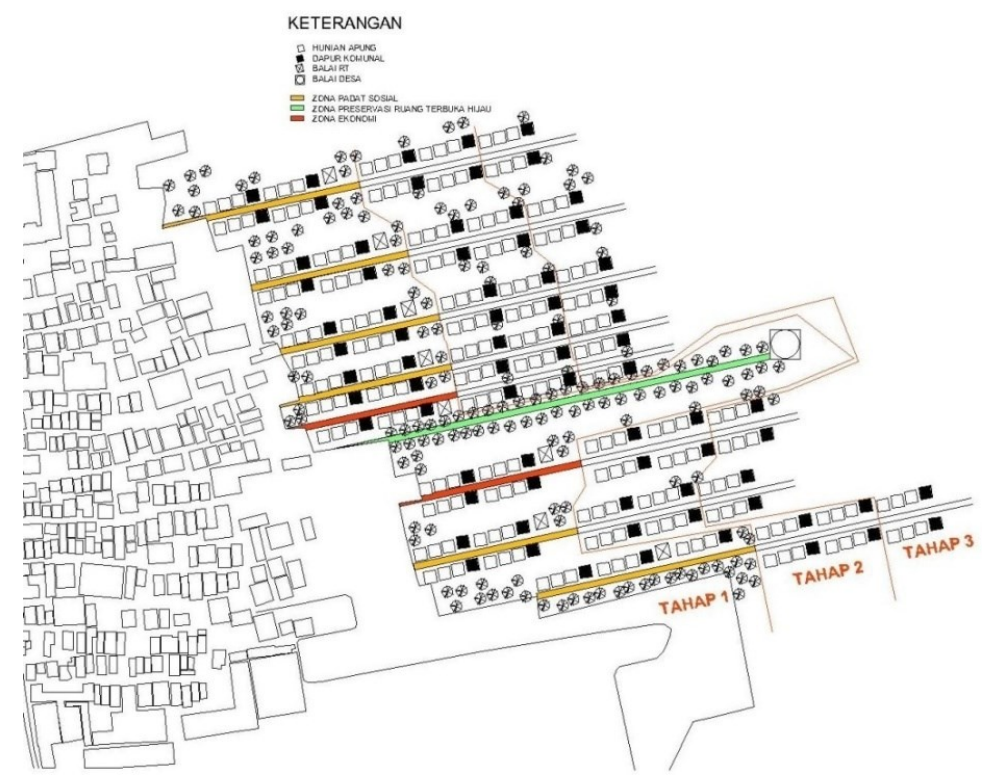

Gambar 5. Perencanaan Pengembangan Kawasan Kampung Nelayan Sukolilo

(Sumber: dokumen penulis, 2020).

Cluster Zoning diterapkan dengan membagi area permukiman menjadi beberapa kelompok sesuai fungsi perencanaan. Hal ini didasarkan pada pengendalian pengembangan kawasan Kampung Nelayan Sukolilo. Dalam bentuk cluster yaitu cluster zona ekonomi, cluster zona padat sosial, dan cluster zona preservasi ruang terbuka hijau. Pada gambar 5 terlihat dimana penempatan zona ekonomi berada pada gang 3 dan 5 yang berada dekat pada zona preservasi ruang terbuka hijau. Hal ini bertujuan agar memberi ruang tersendiri untuk pengendalian sirkulasi dengan tidak mencampurkan zona ekonomi dan zona padat sosial atau hunian. disamping menghilangkan kesan kumuh dari zona ekonomi tersebut. 


\subsection{Konsep Pengembangan Kawasan Linear Berkala}

Pengembangan kawasan linear berkala bertujuan mengurangi eksploitasi secara berlebihan yang berakibat terganggunya keseimbangan ekosistem eksisting. Pengembangan kawasan linier berkala juga memberi ruang jeda dalam proses adaptasi masyarakat terhadap lingkungan yang baru. Proses pengembangan dari kawasan Kampung Nelayan Sukolilo diklasifikasikan ke dalam tiga tahap yaitu:

\subsubsection{Pengembangan Hunian Skala Kecil dan Cluster Preservasi Ruang Terbuka Hijau}

Pada tahap pertama ini, pengembangan dari kawasan Kampung Nelayan Sukolilo dimulai dari pembangunan hunian apung dalam skala kecil, dan pembentukan cluster zona preservasi ruang terbuka hijau dengan cara melakukan penanaman bibit bakau pada lahan bakal terbangun. Tujuannya mengurangi dampak eksploitasi berlebihan terhadap ekosistem dari lahan eksisting. Dan tanaman mangrove dapat difungsikan untuk mengurangi dampak dari abrasi laut, serta dapat menjadi menjadi pemecah ombak. Pada tahap ini diharapkan masyarakat dapat beradaptasi terhadap gaya hidup baru tinggal di permukiman terapung.

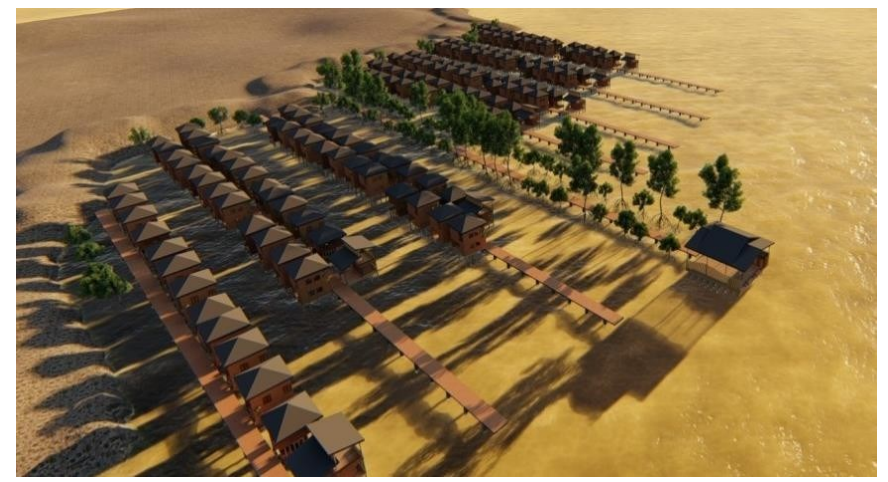

Gambar 6. Birdview Rancangan kawasan Kampung Nelayan Sukolilo

(Sumber: dokumen peneliti, 2020).

\subsubsection{Pengembangan Hunian dan Infrastruktur Kawasan Berupa Fasilitas Sosial, Serta Penambahan Zona Ekonomi}

Pada tahap ini, dilakukan penambahan jumlah hunian dan peningkatan kualitas infrastruktur yang berupa akses sirkulasi, dan penambahan fasilitas sosial seperti balai RT. Juga mulai ditambahkan zona ekonomi berupa stan penjualan produk olahan hasil laut.

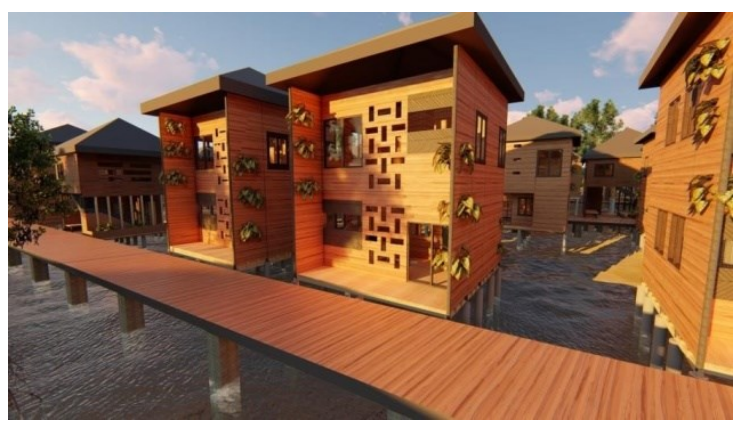

Gambar 7. Tampilan Hunian Apung

(Sumber: dokumentasi peneliti 2020)

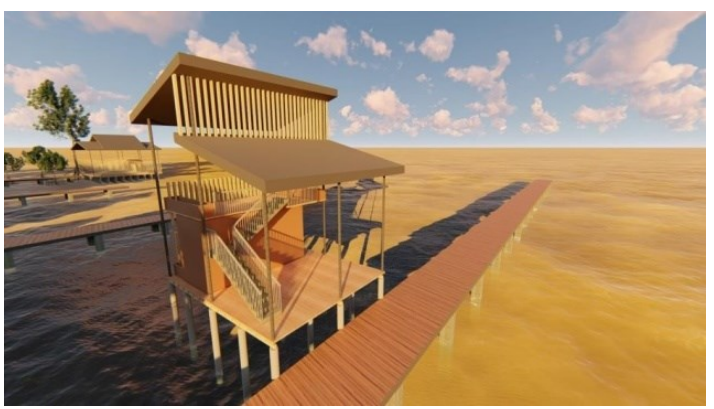

Gambar 8. Tampilan Balai RT

(Sumber: dokumentasi peneliti 2020).

\subsubsection{Pengembangan Hunian dan Peningkatan Kualitas Kawasan}

Tahap ini ditambahkan fasilitas penunjang kawasan berupa balai warga sebagai tempat berkumpul para warga dan dapat dijadikan sebagai landmark kawasan Kampung Nelayan Sukolilo. Juga dibangun Puskesmas sebagai fasilitas penunjang kesehatan bagi masyarakat di kawasan tersebut. Peningkatan infrastruktur kawasan, sehingga menambah daya mobilitas masyarakat pada kawasan tersebut. Hal ini secara signifikan akan meningkatkan kualitas dari permukiman pesisir tersebut. 
Pengembangan fasilitas hunian meliputi perencanaan desain rumah yang mempertahankan fasad lingkungan permukiman lama. Denah rumah terdiri dari 2 lantai, lantai 1 merupakan ruang terbuka yang berfungsi sebagai ruang komunal dan lantai 2 untuk fungsi kegiatan yang lebih privat, yaitu kamar tidur seperti pada gambar berikut.
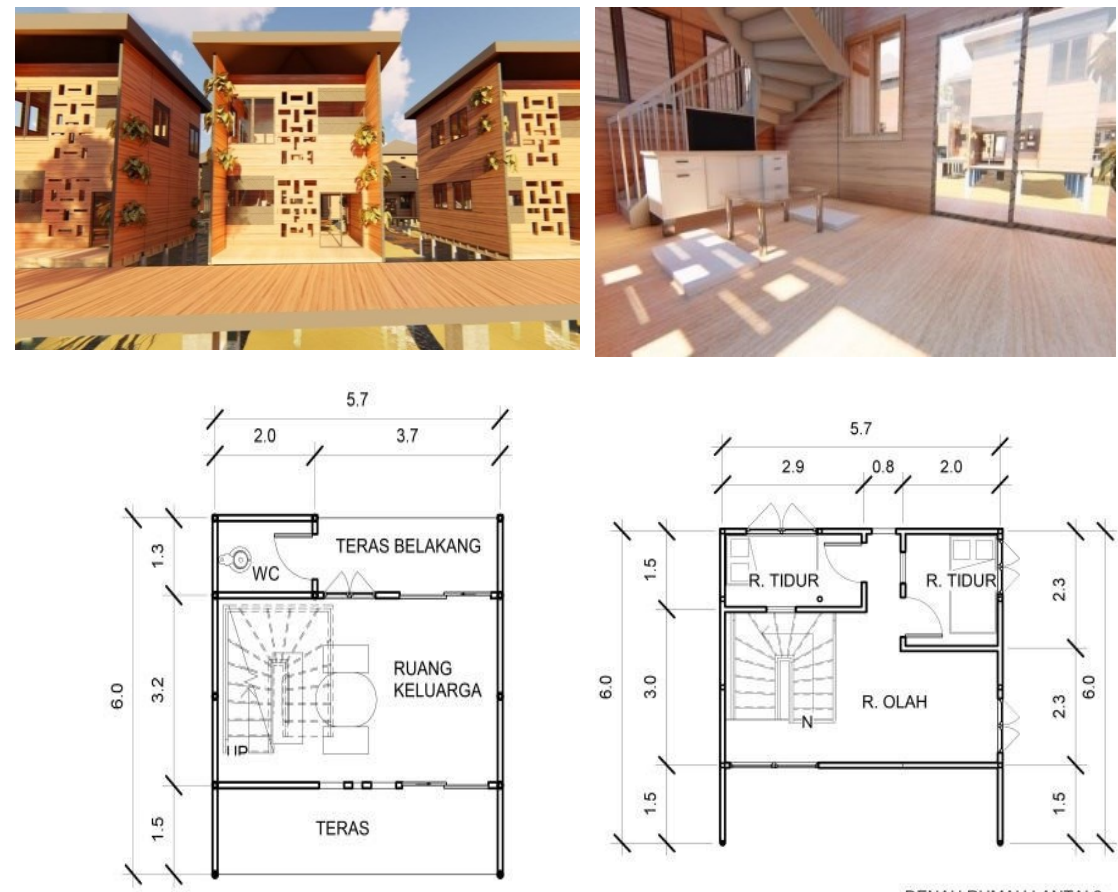

DENAH RUMAH LANTAI 2

DENAH RUMAHLT

Gambar 9. Desain Rumah dan Interior Hunian Apung

(Sumber: dokumen peneliti, 2020).

Penyelesaian ruang luar dengan mengembangkan kawasan preservasi berupa ruang terbuka hijau. Upaya konservasi bagi ekosistem eksistingnya. Dilakukan dengan penanaman bibit bakau di sepanjang area preservasi ruang terbuka hijau sebagai upaya pelestarian ekosistem tersebut. Tanaman bakau memiliki akar yang kuat sehingga dapat menahan muka tanah pesisir dan mencegah ternjadinya abrasi pada daerah pesisir. Selain itu, tanaman bakau dapat digunakan sebagai pemecah gelombang pasang pada daerah pesisir. Dengan demikian, infrastruktur dari permukiman dapat bertahan lebih lama daripada kawasan yang tidak ditumbuhi tanaman bakau tersebut.

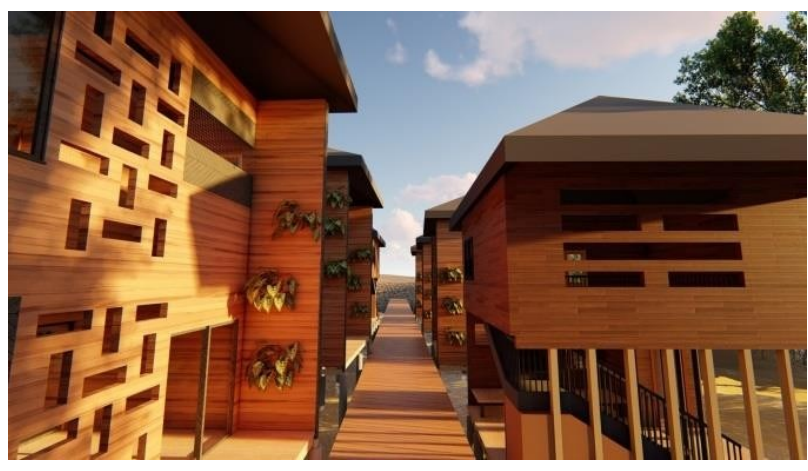

Gambar 10. Ruang Luar Hunian Apung (Sumber: dokumen peneliti, 2020)

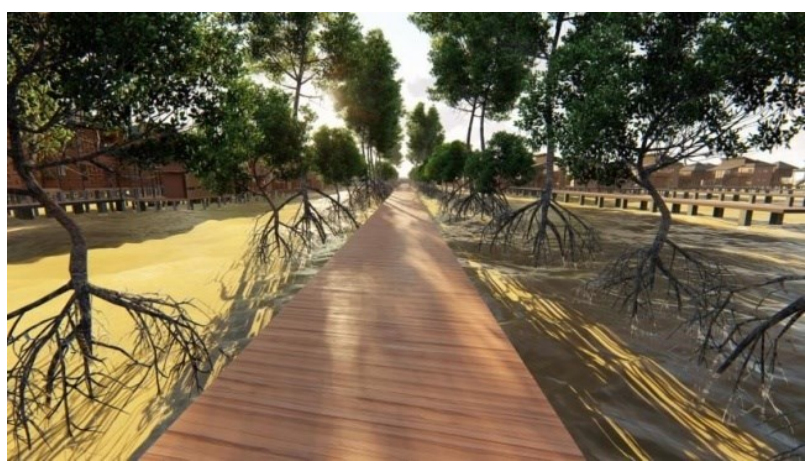

Gambar 11. Ruang Terbuka Hijau (Sumber: dokumen peneliti, 2020)

Keberadaan ruang terbuka hijau menambah kesan asri dan menghilangkan kesan kumuh pada permukiman tersebut dapat menambah produksi udara segar pada kawasan permukiman tersebut. Rancangan kawasan 
permukiman ini juga dilengkapi fasilitas komunal berupa balai warga dengan ukuran 14 x 14 meter. Rancangan bangunan dibuat terbuka. Balai warga juga digunakan untuk kegiatan tahunan warga.

\section{Kesimpulan}

Pengembangan kawasan Kampung Nelayan Sukolilo Baru menjadi salah satu permukiman di kawasan pesisir perlu dilakukan secara bertahap. Hal ini bertujuan agar tidak terjadi eksploitasi yang mendadak dan luas karena akan berpengaruh terhadap kondisi ekosistem Pantai. Pengembangan bertahap juga memberi kesempatan kepada masyarakat yang menempati permukiman tersebut dapat beradaptasi dari lingkungan permukiman landed yang berdiri diatas tanah menuju permukiman terapung. Pengembangan permukiman pesisir kampung nelayan Sukolilo baru dengan desain kampung apung merupakan konsep rancangan yang berusaha menyesuaikan dengan kondisi lingkungan atau menyesuaikan dengan konteksnya, yaitu tepi pantai. Namun, pada perancangan ini masih kurang akan data perancangan utilitas dan perlakuan terhadap ekosistem pesisir kawasan tropis lembab. Diharapkan pada masa mendatang agar pemenuhan data tersebut dapat meningkatkan kualitas dari realisasi pengembangan kawasan Kampung Nelayan Sukolilo tersebut.

\section{Ucapan Terima Kasih}

Puji Syukur dipanjatkan kepada Tuhan Yang Maha Esa atas limpahan Rahmat dan Karunia-Nya, sehingga Karya Ilmiah ini dapat terselesaikan. Terima kasih kami ucapkan kepada Ibu Fairuz Mutia, ST., MT. selaku dosen pengampu mata kuliah Teori Arsitektur dan Ibu Ir. Sri Suryani Yuprapti Winasih, MT. selaku dosen pembimbing yang banyak memberi bantuan, kritik dan saran dalam penyelesaian karya ilmiah ini. Terima kasih kepada keluarga dan orang-orang terdekat kami atas bantuan dukungan berupa materi, moral dan doa untuk menyelesaikan jurnal ini.

\section{Daftar Pustaka}

Baun, P. (2008), Kajian Pengembangan Pemanfaatan Ruang Terbangun Di Kawasan Pesisir Kota Kupang, Program Pascasarjana Magister Teknik Pembangunan Wilayah Kota, Universitas Diponegoro.

Dharma, I., (2017), Respon Rumah Tradisional Suku Bajo Terhadap Iklim Tropis, IPLBI 2017, H097-H1 12.

Firgus, H. (2010), 'Pengaruh Konteks Terhadap Desain Arsitektur Kontekstual', Program Studi Arsitektur, Fakultas Teknik, Universitas Indonesia.

Nadya, E. and Winarto, E., 2019, 'Pengembangan Desa Wisata Pengrajin Bambu Yogyakarta Dengan Pendekatan Localism', BORDER, vol. 1, 41-50.

Najib, M., 2010, 'Potensi dan Permasalahan Pengembangan Kawasan Permukiman Wisata Dusun Salena Palu', ruang, vol. 2, 9-19.

Rahayuningtyas, N., Daryanto, T., and Purwani, O., 2017, 'Penerapan Arsitektur Kontekstual Dalam Perancangan Kawasan Wisata Budaya Samin Di Blora', Region, vol.

15 , no. 2, 378-388.

Rifai, A., 2010. 'Perkembangan Struktur Dan Konstruksi Rumah Tradisional Suku Bajo Di Pesisir Pantai Parigi Moutong', ruang, vol. 2, 31-38.

Suharyani, S., 2018, 'Identifikasi Material Scaffolding Sebagai Alternatif Tempat Tinggal Untuk Kalangan Masyarakat Berpenghasilan Rendah (MBR)', SINEKTIKA, vol.15, 23-33.

Wixon, D., Holtzblatt, K., and Knox, S., 1990, 'Contextual Design: An Emergent View of System Design', CHI'90 Proceedings, 329-336.

Alhamdani, M. Ridha, 2010, Strategi dan Aplikasi Pendekatan Kontekstual dalam Perancangan Karya Arsitektural Renzo Piano (tesis), Program Pasca Sarjana Universitas Gadjah Mada, Yogyakarta.

Calthorpe, P., \& Fulton, W. B. (2001). The Regional City: Planning for the end of sprawl. Washington, DC: Island Press. Landry, C. (2006). The art of city-making. London: Earthscan.

Trancik, R. (1986). Finding lost space: Theories of urban design. New York: Van Nostrand Reinhold. 